\title{
COST ES0602: towards a European network on chemical weather forecasting and information systems
}

\author{
J. Kukkonen ${ }^{1}$, T. Klein ${ }^{2}$, K. Karatzas ${ }^{3}$, K. Torseth ${ }^{4}$, A. Fahre Vik ${ }^{4}$, R. San Josée ${ }^{5}$, T. Balk ${ }^{1}$, and M. Sofiev ${ }^{1}$ \\ ${ }^{1}$ Finnish Meteorological Institute, Helsinki, Finland \\ ${ }^{2}$ Swedish Meteorological and Hydrological Institute, Norrköping, Sweden \\ ${ }^{3}$ Aristotle University, Thessaloniki, Greece \\ ${ }^{4}$ Norwegian Institute for Air Research, Kjeller, Norway \\ ${ }^{5}$ Computer Science School, Technical University of Madrid (UPM), Spain
}

Received: 11 December 2008 - Revised: 14 March 2009 - Accepted: 20 March 2009 - Published: 7 April 2009

\begin{abstract}
The COST ES0602 action provides a forum for benchmarking approaches and practices in data exchange and multi-model capabilities for chemical weather forecasting and near real-time information services in Europe. The action includes approximately 30 participants from 19 countries, and its duration is from 2007 to 2011 (http://www.chemicalweather.eu/). Major efforts have been dedicated in other actions and projects to the development of infrastructures for data flow. We have therefore aimed for collaboration with ongoing actions towards developing near real-time exchange of input data for air quality forecasting. We have collected information on the operational air quality forecasting models on a regional and continental scale in a structured form, and inter-compared and evaluated the physical and chemical structure of these models. We have also constructed a European chemical weather forecasting portal that includes links to most of the available chemical weather forecasting systems in Europe. The collaboration also includes the examination of the case studies that have been organized within COST-728, in order to inter-compare and evaluate the models against experimental data. We have also constructed an operational model forecasting ensemble. Data from a representative set of regional background stations have been selected, and the operational forecasts for this set of sites will be inter-compared and evaluated. The Action has investigated, analysed and reviewed existing chemical weather information systems and services, and will provide recommendations on best practices concerning the presentation and dissemination of chemical weather information towards the public and decision makers.
\end{abstract}

\section{Introduction}

It would be cost-effective and beneficial for citizens, society and decision-makers that national chemical weather forecast and information systems would be harmonized across Europe. The COST ES0602 action has provided a forum for the evaluation and assessment of modelling and information systems for chemical weather and air quality forecasting. It has been complementary with several ongoing projects and initiatives that have the same or similar goals. In particular, it has served as a platform for the information exchange between the meteorological services, research institutes and environmental agencies.

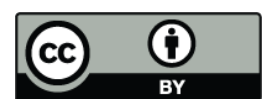

Correspondence to: J. Kukkonen

(jaakko.kukkonen@fmi.fi)
Methods that include a combination of weather forecasting and atmospheric chemistry simulations are here referred to as chemical weather forecasting. The definition of chemical weather therefore extends the concept of air quality forecasting. For instance, air quality forecasting models using statistical methods that are not based on weather forecasting models, are therefore by definition not chemical weather forecasting models. Chemical weather forecasting requires access to meteorological and air pollutant concentration fields and measurements (both in situ and remote-sensing), emission inventories and physiographic data. The users of chemical weather or air quality forecasts include European citizens, public authorities and agencies that are in charge of environmental impact assessments and public health. 
Especially European National Meteorological Services, but also a number of research institutes have a long-term expertise on handling and disseminating extensive amounts of data in near-real-time, data assimilation and numerical forecasting model systems. However, there is a wide variety of institutes and organisations in Europe that are responsible on national levels for operating air quality monitoring networks, managing concentration data and providing air quality assessments. The European Environment Agency has established the European Environment Information and Observation Network (EIONET, http://air-climate.eionet.eu.int/) for environmental information transfer, and the "Ozoneweb" information system (http://www.eea.europa.eu/maps/ozone/ welcome) as a pilot system for demonstrating seamless, near real time air quality information dissemination.

There are currently numerous Air Quality Forecasting and Information Systems (AQFIS's) on a local, regional and continental scale in Europe. Some prominent examples are the following: the EURAD modelling system in Germany (Elbern et al., 2007, http://www.eurad.uni-koeln.de/index_e. html), the PREVAIR consortium (Menut et al., 2005, http: //www.prevair.org/en/index.html) and the air quality forecasting and simulation system MM5-CHIMERE (Vautard et al., 2005, http://www.mmm.ucar.edu/mm5/, http://www.lmd. polytechnique.fr/chimere/) in France, the "Your Air-" system in England and Wales (http://www.cerc.co.uk/YourAir), the SILAM consortium coordinated in Finland (Sofiev et al., 2006, http://silam.fmi.fi), the European Operational Air Quality Forecasting system EOAQF (http://verde.lma. fi.upm.es/cmaq_eu/) in Spain, the MATCH AQ Forecast and Information System (MAQS) in Sweden (Robertson et al., 1999, and http://www.airviro.smhi.se/MATCH-AQ/ maqs) the AIRTHESS air quality information, forecasting and early warning system in the Greater Thessaloniki Area (http://www.airthess.gr).

Clearly, any single modelling approach includes inherent limitations and uncertainties. The higher-resolution domains also commonly cover only a limited area, characteristically one or a few European countries. The COST ES0602 action therefore evaluates and inter-compares both the mathematical structure and the predictions of these modelling systems, as well as the way that information is presented and disseminated to the end users.

However, there are various institutional, scientific and practical obstacles for an overall seamless exchange of data and forecast information dissemination. A European network of chemical weather forecasting and information systems will require a high level of coordination between various participants in near real-time. Such a system should integrate data collection and processing, forecasting, as well as management, display and dissemination of chemical weather forecasts. The aim of this COST Action is therefore to provide a platform to bridge the gaps between the scientific community (e.g., universities), providers of infrastructure (such as the national meteorological services), environmen- tal agencies, the observation and the modelling community and the user community.

The COST ES0602 action contains three main fields of work. The first one comprises the analysis of existing data flows and information exchange, as well as the improved pan-European integration with regard to both air quality measurements and model results. The second area of work focuses on the modelling aspects, including the multi-model approaches for the forecasting of air quality. The third field of work of this COST Action is about the dissemination of AQ information to the user community and its use to construct information services for the quality of life. The main objective of this paper is to review the achievements of this COST action within these three areas.

\section{Work programme and achievements of the action}

\subsection{The relations of this action with other prominent projects in progress}

There are prominent ongoing European projects in this area, in particular within the EU-ESA (European Space Agency) programme GMES (Global Monitoring for Environment and Security, http://www.europa.eu.int/comm/space/gmes/ index_en.htm), such as GEMS (http://gems.ecmwf.int/) and PROMOTE (PROtocol MOniToring for the GMES Service Element, http://www.gse-promote.org/, Poupkou et al., 2006). The GMES Atmospheric Services focus on operational monitoring and forecasting of atmospheric composition, dynamics and thermodynamics through advanced exploitation of satellite and in-situ data, on a European, national and local level. Clearly, currently there are also several other related EU-funded projects, such as MEGAPOLI (Baklanov et al., 2008), CITYZEN, EUCAARI (http://www.atm. helsinki.fi/eucaari/) and EUSAAR (http://www.eusaar.net/).

Within the GEMS project, analyses and $72 \mathrm{~h}$ forecasts have been presented using ten state-of-the-art regional air quality models from nine countries (BOLCHEM, CAC, CHIMERE, EMEP, EURAD, MATCH, MOCAGE, MM5UAMV, NAME and SILAM) on a quasi-operational daily basis (http://www.ecmwf.int/). The models rely on the operational meteorological forecasts of the European Centre for Medium-Range Weather Forecasts, as well as on GEMS global chemical weather data. They all consider the same high-resolution $(\sim 8 \mathrm{~km})$ anthropogenic and biogenic emissions inventories.

An example of a small-scale network of a few operational air quality services has been constructed within the first and second stages of the PROMOTE project. These projects, however, have a selected membership and are developmentoriented; these can not therefore involve all stake-holders in a comprehensive way, such as the national environmental agencies. This COST action provides a forum with a broader membership across the different communities, in order to complement and extend these projects. 
Another relevant activity is the Global Earth Observation and Monitoring (GEOmon) project (www.geomon.eu), the goal of which is to sustain and analyze European ground based observations of atmospheric composition and their complementarity with satellite observations. It aims to lay the foundation for a European contribution to GEOSS (Global Earth Observation System of Systems, http://www. epa.gov/geoss/) and to optimize the European strategy of environmental monitoring in the field of atmospheric composition measurements. Key deliverables include the provision of access to data through a common data centre (for atmospheric composition data), and the dissemination of data and data products through user friendly tools.

\subsection{The main achievements of the action}

COST ES0602 started its work in April 2007 and has an overall duration of four years. The following 19 COST countries have actively participated in the Action: Austria, Bulgaria, Denmark, Estonia, Finland, France, Germany, Greece, Hungary, Israel, Italy, the Netherlands, Norway, Poland, Portugal, Slovenia, Spain, Sweden, and the United Kingdom. The achievements of the three working groups of the Action are described in the following subsections.

\subsubsection{Exchange of $A Q$ forecasts and input data}

The first field of work comprises the analysis of existing data flows and information exchange as well as the improvements towards a pan-European integration with regard to both air quality and meteorological measurements and model results. The major areas and key tasks are the identification of requirements for data exchange needed for effective chemical weather forecasting and the investigation of infrastructure needed to meet the identified demands.

One relevant initiative is the Ozone web developed by the EEA (European Environment Agency; http://www.eea. europa.eu/maps/ozone/map), which has been planned to be extended to contain also particulate matter mass-based concentration data in the near future. This solution is based on data flow from national air quality information solutions. There has also been a pilot study on replacing ozone summer reporting based on the ozone web. The main focus is on information to public and on legislative parameters (more than 700 stations), and the EEA aims to develop this further as an important pillar in the in-situ data provision for the Atmosphere Core Service of GMES.

The GMES process also takes measures to coordinate the in-situ data provision. There are numerous challenges in this area, as follows: (i) inadequate monitoring and limited geographical coverage of concentration values, in particular ground surface $\mathrm{PM}_{2.5}, \mathrm{CO}$ and VOC's, (ii) a limited sustainability of certain measurements, especially those initiated within research programmes, (iii) inadequate emissions data for air quality modeling, (iv) insufficient timeliness of concentration data availability (i.e., delivery of data in near real time), (v) inadequate availability of near real time meteorological data for modelers, and (vi) limited sustainability of in-situ infrastructure, in particular for vertical concentration information (especially for ozone, aerosol, $\mathrm{CO}, \mathrm{NO}_{\mathrm{x}}$ and $\mathrm{CO}_{2}$ ).

Another challenging issue is the lack of interchange between networks and of common Quality Assurance standards, common data formats and conversion of data used in different networks and for different purposes. There is a clear need for traceable and harmonized data quality across various networks.

Another established infrastructure for in-situ observation data is the EMEP programme (European Monitoring and Evaluation Programme; www.emep.int/). It has focused on transboundary air pollution and it has operated about 100 rural background stations. These observations have mainly been set up to allow an assessment of the regional scale transport, transformation and deposition; however, due to challenges such as the evaluation of the adverse health effects of particulate matter, there is a need for a more extensive number of concentration parameters to be measured. Further, the EMEP observations are generally established to ensure comparability across national boundaries on trace concentration levels, instead of the higher values that are of concern from a public health perspective.

Within Europe, the EMEP and the Global Atmospheric Watch programme of the World Meteorological Organisation have agreed to operate joint supersites, and there is also a strong overlap between ordinary regional sites of these two programmes. The EEA and EMEP are currently conducting a specific study to address how the data provision between the two initiatives can be harmonised regarding near real time data provision.

The provision of near real time data has also additional challenges in relation to data ownership, quality assurance and compliance issues. One example of a relevant FP6 project is the European Supersites for Atmospheric Aerosol Research (EUSAAR) project. This is a network of specialised aerosol monitoring stations in the EMEP/GAW network, and where near real time functionalities for advanced aerosol measurements (for instance, size distributions and optical absorption) have been developed. The collection of several instrumental parameters allows implementation of automatic $\mathrm{QA} / \mathrm{QC}$ routines. It is currently in a demonstration mode and acts as precursor for the EMEP near real-time application.

Another relevant initiative is the Citeair project (EU Interreg project). It aims to provide harmonised $A Q$ information from European cities with focus on urban background and roadside stations. Concentration parameters include $\mathrm{NO}_{2}$, $\mathrm{PM}_{10}, \mathrm{O}_{3}, \mathrm{CO}$ and $\mathrm{SO}_{2}$. Only air quality indices are presented (http://www.airqualitynow.eu/). Similarly, the Air CE initiative focus is on Central Europe and it provides public information in the form of colour coded tables of air quality 
Table 1. An overview of the number of stations and the main limitations of selected European near real time concentration datasets. Notation: EEA = European Environment Agency, NRT = near real time, AQ = air quality.

\begin{tabular}{|c|c|c|c|c|c|c|}
\hline Item/Project & $\begin{array}{l}\text { EEA NRT AQ } \\
\text { (e.g. Ozone Web) }\end{array}$ & EMEP & Citeair & GEMS & PROMOTE & EUSAAR \\
\hline $\begin{array}{l}\text { Number of measurement } \\
\text { points }\end{array}$ & More than 700 & $\begin{array}{l}100-120 \text { rural } \\
\text { background stations }\end{array}$ & $\begin{array}{l}\text { Measurement stations } \\
\text { from } 26 \text { cities }\end{array}$ & More than 800 & More than 100 & 20 \\
\hline Limitations & $\begin{array}{l}\text { Only a few parameters } \\
\text { currently implemented. } \\
\text { Based on a large num- } \\
\text { ber of data providers, } \\
\text { various QA procedures. }\end{array}$ & $\begin{array}{l}\text { Only rural background } \\
\text { stations. In a planning } \\
\text { stage, no data yet sub- } \\
\text { mitted. }\end{array}$ & $\begin{array}{l}\text { Only AQ indices avail- } \\
\text { able and only from a few } \\
\text { cities across Europe. }\end{array}$ & $\begin{array}{l}\text { The data are available } \\
\text { only based on bilateral } \\
\text { agreements. }\end{array}$ & $\begin{array}{l}\text { Data are only available } \\
\text { on the basis of Service } \\
\text { Level Agreements to ser- } \\
\text { vice providers. }\end{array}$ & $\begin{array}{l}\text { Only } 20 \text { sites available } \\
\text { and limited prospects for } \\
\text { increase. Main focus on } \\
\text { process studies, not air } \\
\text { quality monitoring. }\end{array}$ \\
\hline
\end{tabular}

levels $\left(\mathrm{SO}_{2}, \mathrm{NO}_{2}, \mathrm{O}_{3}, \mathrm{PM}_{10}\right.$, and meteorological parameters; http://airce.info/en/).

An overview of selected European near real time datasets has been presented in Table 1, regarding the number of stations and the main limitations.

The World Meteorological Organisation Information System (WIS) may provide a common exchange method for in situ data in the future. However, it is currently in a design phase, and as most data providers of air quality are not meteorological services, it is under consideration to set up a WIS-connection from the already existing concentration data centres (e.g., EEA and EMEP). On a more overarching level, several initiatives are in progress. These obviously include the GEOSS process, and the implementation of the INSPIRE and SEIS (http://ec.europa.eu/environment/ seis/index.htm) directives.

\subsubsection{Multi-scale forecasting, multi-model ensembles and boundary data}

The objectives are to analyse the existing experience on chemical weather forecasting, to enhance and organise various joint efforts of European modelling teams and finally, to design a set of recommendations for the future research in the area.

We have reviewed the mathematical structure and computer implementations of operational chemical weather forecasting models on regional and continental scales. The main sources of information on the modelling systems currently in use were (i) the available literature and internet resources, (ii) more detailed information provided by the WG2 participants, (iii) the COST-728 (www.cost728.org) and EEA databases of the existing modelling systems. In particular, a related overview of integrated mesoscale meteorological and chemical transport modelling systems in Europe has been compiled in collaboration of COST-728 and GURME (Baklanov et al., 2008). However, this report did not aim at a systematic evaluation or inter-comparison of the various systems.

Some example results of the inter-comparison of the mathematical structure of such models have been presented in Table 2. This study aims to evaluate the relative advantages and limitations of various modeling systems, present prominent gaps of knowledge, and suggest priority directions for future research.

We have also constructed a European chemical weather forecasting portal that includes links to available chemical weather forecasting systems in Europe in a user-friendly graphical format (http://www.chemicalweather.eu/Domains; Fig. 1). The user can select any location on the European map, and will automatically receive a list of the available air quality forecasting systems that contain predictions for the selected geographic location, links to those, as well as other relevant information regarding these systems. Such a single point of reference for the European chemical weather forecasting information has not been operational previously. In the future, more modelling domains will be included, as well as guidance on the selection and use of these models.

Ensemble forecasts have become standard practice in meteorology, e.g., the EPS system of the European Centre for Medium-Range Weather Forecasts, but they have yet fairly rarely been applied to air pollution forecasting. There are two prominent examples of ensemble dispersion modelling (i) in emergency preparedness, in the project ENSEMBLE, (Galmarini et al., 2004a, b; http://ensembles-eu.metoffice.com/) and (ii) in chemical weather forecasting in the GEMS project (Global Earth-system Monitoring using Space and in-situ data; http://gems.ecmwf.int/). Multi-model approaches can be used to enrich the information provided by the individual deterministic models with probabilistic information, such as the range of uncertainties.

Work is in progress in this COST action in order to construct an operational model forecasting ensemble. A representative set of regional background stations have been selected from the participating countries, and the operational forecasts for this set of sites will be inter-compared and evaluated. The modelling groups have started to collect the information, and we aim to evaluate the ensemble performance in 2009.

We also inter-compare and evaluate the predictions of regional and continental scale air quality models against experimental data. Selected examples of the previous intercomparisons are those organized by EUROTRAC and EMEP, and the City-Delta project. The international model evaluation and inter-comparison exercises have been previously useful for comparing the mathematical treatments of the 
Table 2. Inter-comparison of selected properties of the mathematical structure of a few selected European chemical weather forecasting models on regional and continental scales.

\begin{tabular}{|c|c|c|c|c|c|c|}
\hline & \multicolumn{2}{|c|}{ Model types } & \multicolumn{4}{|c|}{ Treatments of physical and chemical processes } \\
\hline & $\begin{array}{l}\text { Dispersion and } \\
\text { Chemistry }\end{array}$ & Meteorology & Advection \& convection & Turbulence & Deposition & Chemistry \\
\hline $\begin{array}{l}\text { LOTOS-EUROS } \\
\text { The Netherlands }\end{array}$ & 3D Eulerian & ECMWF & $\begin{array}{l}\text { Advection based on Walcek } \\
(2000) \text {. Vertical grid follows } \\
\text { planetary boundary layer from } \\
\text { meteorology. }\end{array}$ & $\begin{array}{l}\text { Vertical turbulent mixing based } \\
\text { on K-theory. }\end{array}$ & $\begin{array}{l}\text { Dry: resistance approach. Wet: } \\
\text { scavenging rates depend on } \\
\text { Henry law constants for gases } \\
\text { and Scott (1979) for particles. }\end{array}$ & $\begin{array}{l}\text { Gas phase: updated CBM- } \\
4 \text { with Carter's 1-product iso- } \\
\text { phere scheme: homo- and het- } \\
\text { erogenous conversion of } \mathrm{NO}_{2} \text { to } \\
\mathrm{HNO}_{3} \text {, Aerosol chemistry using } \\
\text { ISORROPIA. }\end{array}$ \\
\hline $\begin{array}{l}\text { MATCH } \\
\text { Sweden }\end{array}$ & 3D Eulerian & ECMWF, HIRLAM & $\begin{array}{l}\text { Bott-type advection scheme } \\
\text { (Bott, 1989). }\end{array}$ & $\begin{array}{l}\text { Vertical turbulent mixing based } \\
\text { on K-theory. }\end{array}$ & $\begin{array}{l}\text { Dry: resistance approach. Wet: } \\
\text { assumed to be proportional to } \\
\text { the precipitation intensity using } \\
\text { species-specific scavenging co- } \\
\text { efficients. }\end{array}$ & $\begin{array}{l}110 \text { thermal, } 28 \text { photochemical, } \\
2 \text { aqueous-phase, } 5 \text { aerosol } \\
\text { reactions and } 4 \text { gas-phase } \\
\text { aqueous-phase and aerosol } \\
\text { equilibria between } 61 \text { chemical } \\
\text { components. Gas phase: based } \\
\text { on the EMEP MSC-W. }\end{array}$ \\
\hline $\begin{array}{l}\text { MM5-CHIMERE } \\
\text { France }\end{array}$ & $\begin{array}{l}\text { CHIMERE (C): } \\
\text { 3D Eulerian }\end{array}$ & MM5 (M) & $\begin{array}{l}\text { M: finite difference formulation } \\
\text { of the time-dependent Navier- } \\
\text { Stokes equations. C: for ad- } \\
\text { vection the parabolic piece- } \\
\text { wise method, the Godunov and } \\
\text { the simple upwind first-order } \\
\text { schemes. }\end{array}$ & $\begin{array}{l}\text { M: several PBL schemes (Bulk } \\
\text { PBL, high resolution Blackadar } \\
\text { PBL, etc.) C: Vertical turbulent } \\
\text { mixing takes place only in the } \\
\text { boundary-layer. K-diffusion, } \\
\text { without counter-gradient term. }\end{array}$ & $\begin{array}{l}\text { M: Nonconvective precipitation } \\
\text { scheme, warm rain, simple } \\
\text { ice, mixed-phase, Goddard mi- } \\
\text { crophysics, Reisner graupel, } \\
\text { Schultz microphysics. C: Dry: } \\
\text { deposition velocity through a } \\
\text { resistance analogy. Wet: based } \\
\text { on Loosmore. }\end{array}$ & $\begin{array}{l}\text { C: Over } 300 \text { reactions of } 80 \\
\text { gaseous species. Hydrocarbon } \\
\text { degradation is similar to the } \\
\text { EMEP gas phase. Adaptations } \\
\text { are made for low NOx con- } \\
\text { ditions and NOx-nitrate chem- } \\
\text { istry. Heterogeneous formation } \\
\text { of HONO from deposition of } \\
\text { NO2 on wet surfaces. }\end{array}$ \\
\hline $\begin{array}{l}\text { NAME } \\
\text { UK }\end{array}$ & 3D Lagrangian & $\begin{array}{l}\text { Met Office Unified } \\
\text { Model }\end{array}$ & $\begin{array}{l}\text { The model uses the convection } \\
\text { scheme of the Unified Model of } \\
\text { the U.K. Met. Office. }\end{array}$ & $\begin{array}{l}\text { Random walk techniques, pa- } \\
\text { rameterised profiles of turbu- } \\
\text { lences, Gaussian scheme. For } \\
\text { convective conditions skewed } \\
\text { turbulence scheme. }\end{array}$ & $\begin{array}{l}\text { Dry: resistance analogy ap- } \\
\text { proach and sedimentation of } \\
\text { heavy particles. Wet: based on } \\
\text { parameterised scavenging coef- } \\
\text { ficients and differs according to } \\
\text { precipitation type. }\end{array}$ & $\begin{array}{l}\text { Based on the scheme for the } \\
\text { STOCHEM model. } 40 \text { advected } \\
\text { tracers }+18 \text { non-advected, } 140 \\
\text { reactions }+23 \text { photolytic reac- } \\
\text { tions, } 16 \text { emitted species }\end{array}$ \\
\hline $\begin{array}{l}\text { OPANA } \\
\text { Spain }\end{array}$ & 3D Eulerian & MEMO & $\begin{array}{l}\text { Monotonic scheme with geo- } \\
\text { metric non-linear adjustments } \\
\text { to the parabolic concentration } \\
\text { distributions. }\end{array}$ & $\begin{array}{l}\text { Blackadar and ACM. Local dif- } \\
\text { fusion, smooth transition from } \\
\text { stable to convective. Updated } \\
\text { eddy diffusion scheme. }\end{array}$ & $\begin{array}{l}\text { Gases: Wesley (1989) Aerosol } \\
\text { chemistry: Schemes are based } \\
\text { on the resistance approach } \\
\text { which assumes a canopy, aero- } \\
\text { dynamical and bulk resistance. }\end{array}$ & $\begin{array}{l}\text { The CBM-IV chemical mecha- } \\
\text { nism in short and long modes. } \\
\text { The RADM model. SAPRC- } 99 \\
\text { chemical scheme. The chemical } \\
\text { reactions in the atmosphere for } \\
\text { organic and inorganic reactions. }\end{array}$ \\
\hline $\begin{array}{l}\text { SILAM } \\
\text { Finland etc. }\end{array}$ & $\begin{array}{l}\text { 3D Lagrangian and } \\
\text { 3D Eulerian }\end{array}$ & ECMWF, HIRLAM & $\begin{array}{l}\text { Lagrangian kernel uses the } \\
\text { iterative advection of Eerola } \\
\text { (1990). Eulerian kernel is based } \\
\text { on Galperin (2000). }\end{array}$ & $\begin{array}{l}\text { Lagrangian kernel assumes } \\
\text { the well-mixed ABL and fixed } \\
\text { random-walk parameters in } \\
\text { the free troposphere. Eulerian } \\
\text { based on the K-theory. }\end{array}$ & $\begin{array}{l}\text { Aerosols: gravitational and dif- } \\
\text { fusional paths are considered. } \\
\text { Wet: scavenging coefficient ap- } \\
\text { proach, distinguished between } \\
\text { the in- and sub-cloud, as well as } \\
\text { rain- snow- types of scavenging. }\end{array}$ & $\begin{array}{l}\text { Basic acid and ozone chemi- } \\
\text { cal transformations, for Eule- } \\
\text { rian kernel. } \mathrm{SO}_{\mathrm{x}} \text { module, suit- } \\
\text { able for both kernels. Radioac- } \\
\text { tive decay of up to } 500 \mathrm{nu}- \\
\text { clides. Toxic species. Inert } \\
\text { aerosol of arbitrary size. Natu- } \\
\text { ral birch pollen. Sea salt. }\end{array}$ \\
\hline
\end{tabular}

state-of-the-art models, and for providing information about the variability of model predictions. We have therefore joined the case studies that have been organized within COST-728, in order to inter-compare and evaluate the models against new sets of experimental data.

\subsubsection{Dissemination and visualization}

The main goal is to streamline the dissemination of air quality information to users (e.g., the public and decision makers). The importance of providing user-tailored information, i.e., the required content in the appropriate presentation form through the most commonly used communication channels has been outlined previously, e.g., by Karatzas (2007). For this purpose, we address several key questions: which information should be selected for the dissemination, how to present and visualise it, how to use it in compiling environmental information services, and which harmonization procedures should be applied. We have also reviewed informa- tion on Air Quality Information and Dissemination Systems in Europe.

Within this activity, the action investigates the potential of a European chemical weather forecasting portal, which integrates and tailors information content from a number of various sources (Fig. 1). This interactive website is scheduled to perform two main functions. First, it will act as a public domain forum, through which the forecasts provided by the participating countries can be viewed. The second function of the website will be to provide an access (via a password protected facility) to an operational database that stores predicted data for model inter-comparison and development purposes.

This European air quality forecasting portal could directly support ongoing European efforts such as the GMES service streams that are currently under development and implementation, and the concept of the Shared Environmental Information System. In a global context, it could be seen as a contribution to the Global Earth Observing System of Systems implemented by the Group on Earth Observations, and as a 


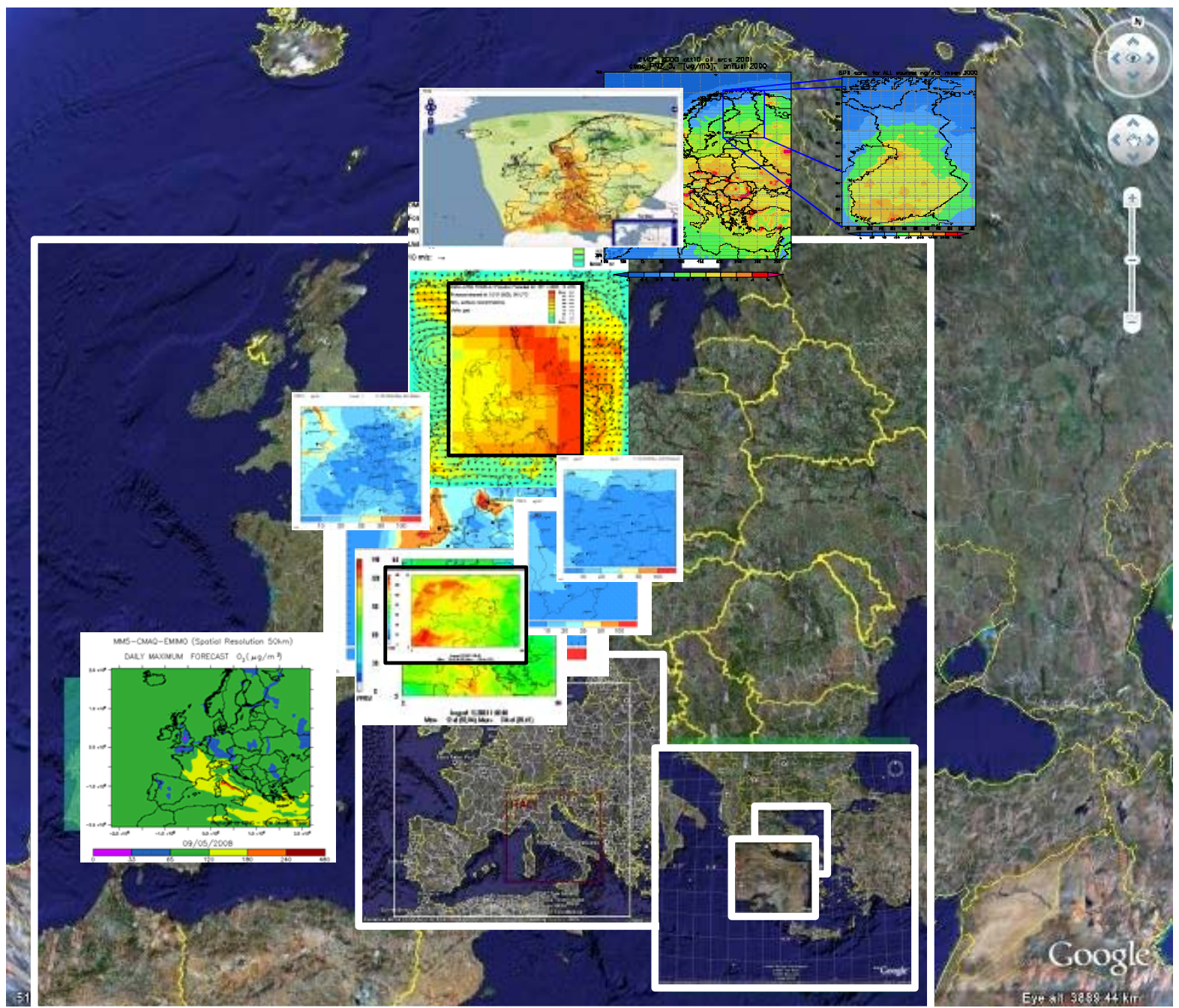

Figure 1. A graphical illustration of the European chemical weather forecasting portal that provides a direct gateway to various national and international CW forecast and information systems in Europe. Only some selected web-based services have been presented in the figure.

platform, upon which various user- and region-customised services may be developed and operated.

In the frame of the Working Group, a workshop has been organised in Thessaloniki, Greece, on 8 May 2008, focusing on "Chemical weather information services for quality of life". The main objectives of the workshop were to improve the exchange of information and promote discussion on the information services related to chemical weather forecasting and air quality monitoring data (Karatzas and Kukkonen, 2009).

\section{Summary and outlook}

The COST Action ES0602 aims at a better integration of existing assets towards the goal of effective chemical weather forecasting in Europe. The Action has already established a wide network of European and global contacts and collabo- rations with numerous related institutes and actions. In addition to the Workshop " $\mathrm{CW}$ information services for quality of life" and a summer school, it has supported several special sessions at conferences and currently preparing more workshops (http://www.chemicalweather.eu/). Seven Short Term Scientific Missions have been performed and more are underway.

The action aims to keep close good contacts with key organisations and actions in Europe, such as EEA, ECMWF, GEMS, GEOMON, PROMOTE, MACC, MEGAPOLI, CITYZEN, EUSAAR, and the relevant COST actions, especially COST-728 and COST ES0603. The action plans to use the work accomplished, e.g., in the GEMS, PROMOTE and ACCENT (http://www.accent-network.org/) projects, and in COST 728. We also intend to improve the contacts outside Europe, e.g., with the US-EPA and the GURME action of the WMO. 
Several promising activities are in progress, such as the European chemical weather forecasting portal. The writing of numerous joint articles is also in progress. We are currently organising several special conference sessions and two more Workshops. The subsequent workshop will address the modelling of chemical weather, and it will be organised in spring 2009 in Budapest.

Acknowledgements. This paper has been part of the action COST ES0602.

Edited by: M. Piringer

Reviewed by: two anonymous referees

\section{References}

Baklanov, A., Fay, B., Kaminski, J., and Sokhi, R.: Overview of existing intergrated (off-line and on-line) mesoscale meteorological and chemical transport modelling systems in Europe, Joint Report of COST Action 728 (Enhancing Mesoscale Meteorological Modelling Capabilities for Air Pollution and Dispersion Applications) and GURME (GAW Urban Research Meteorology and Environment Project), GAW Report No. 177, World Meteorological Organization, COST Office, 2008, ISBN 978-1-905313-563, 2008.

Baklanov, A., Lawrence, M., Pandis, S., and the MEGAPOLI team: New EC 7FP Project MEGAPOLI: Megacities: Emissions, urban, regional and Global Atmospheric pollution and climate effects, and Integrated tools for assessment and mitigation, Geophys. Res. Abstr., 10, EGU2008-A-08126, 2009.

Bott, A.: A positive definite advection scheme obtained bynonlinear renormalization of the advective fluxes, Mon. Weather Rev., 117, 1006-1015, 1989.

Eerola, K.: Experimentation with a three-dimensional trajectory model, FMI Meteorological Publication 15, 33 pp., 1990.

Elbern, H., Strunk, A., Schmidt, H., and Talagrand, O.: Emission rate and chemical state estimation by 4-dimensional variational inversion, Atmos. Chem. Phys., 7, 3749-3769, 2007, http://www.atmos-chem-phys.net/7/3749/2007/.

Engardt, M., Siniarovina, U., Khairul, N. I., and Leong, C. P.: Country to country transport of anthropogenic sulphur in Southeast Asia, Atmos. Environ., 39, 5137-5148, 2005.

Galmarini, S., Bianconi, R., Klug, W., Mikkelsen, T., Addis, R., Andronopoulos, S., Astrup, P., Baklanov, A., Bartniki, J., Bartzis, J. C., Bellasio, R., Bompay, F., Buckley, R., Bouzom, M., Champion, H., D'Amours, R., Davakis, E., Eleveld, H., Geertsema, G. T., Glaab, H., Kollax, M., Ilvonen, M., Manning, A., Pechinger, U., Persson, C., Polreich, E., Potemski, S., Prodanova, M., Saltbones, J., Slaper, H., Sofiev, M. A., Syrakov, D., Sùrensen, J.H., Van der Auwera, L., Valkama, I., and Zelazny, R.: Can the confidence in long-range atmospheric transport models be increased? The pan-European experience of ENSEMBLE, Radiation Protection Dosimetry, 109, Nos 1-2, 19-24, doi:10.1093/rpd/nch261, 2004a.
Galmarini, S., Bianconi, R., Klug, W., Mikkelsen, T., Addis, R., Andronopoulos, S., Astrup, P., Baklanov, A., Bartniki, J., Bartzis, J. C., Bellasio, R., Bompay, F., Buckley, R., Bouzom, M., Champion,H., D’Amours, R., Davakis, E., Eleveld, H., Geertsema, G. T., Glaab, H., Kollax, M., Ilvonen, M., Manning, A., Pechinger, U., Persson, C., Polreich, E., Potemski, S., Prodanova, M., Saltbones, J., Slaper, H., Sofiev, M. A., Syrakov, D., Sørensen, J. H., Van der Auwera, L., Valkama, I., and Zelazny, R.: Ensemble dispersion forecasting - Part I: concept, approach and indicators, Atmos. Environ., 38, 28, 4607-4617, 2004b.

Galperin, M. V.: The Approaches to Correct Computation of Airborne Pollution Advection, in: Problems of Ecological Monitoring and Ecosystem Modelling, vol. XVII, St. Petersburg, Gidrometeoizdat, 54-68, 2000.

Karatzas, K.: State-of-the-art in the dissemination of AQ information to the general public, Proceedings of the 21st International Conference on Informatics for Environmental Protection - EnviroInfo2007, edited by: Hryniewicz, O., Studziñski, J., and Romaniuk, M., Vol. 2, Shaker Verlag, Aachen, 2007, ISBN 978-38322-6397-3, 41-47, 2007.

Karatzas, K. and Kukkonen, L. (Eds.): Quality of life information services towards a sustainable society for the atmospheric environment, Sofia Publishers, Thessaloniki, Greece, ISBN 978-9606706-20-2, 2009.

Menut, L., Honore, C., Rouil, L., Beekmann, M., Vautard, R., Poisson, N., Peuch, V. H., and Rico, M.: PREVAIR, a modeling platform for the air quality predictability study, Geophys. Res. Abstr., 7, 04449, 2005.

Poupkou, A., Melas, D., Kioutsioukis, I., Lisaridis, I., Symeonidis, P., Balis, D., Karathanasis, S., and Kazadzis, S.: Regional air quality forecasting over Greece within PROMOTE, Atmospheric Science Conference, 8-12 May 2006, ESA ESRIN, Frascati, ESA SP-628, published on CD-ROM, p. 85.1, 2006.

Robertson, L., Langner, J., and Engardt, M.: An Eulerian limitedarea atmospheric transport model, J. Appl. Meteorol., 38, 190210, 1999.

Scott, B. C. Parameterization of sulphate removal by precipitation, J. Appl. Meteorol., 17, 11375-11389, 1979.

Sofiev, M., Siljamo, P., Valkama, I., Ilvonen, M., and Kukkonen, J.: A dispersion modelling system SILAM and its evaluation against ETEX data, Atmos. Environ., 40, 4, 674-685, 2006.

Vautard, R., Bessagnet, B., Chin, M., and Menut, L.: On the contribution of natural Aeolian sources to particulate matter concentrations in Europe: Testing hypotheses with a modeling approach, Atmos. Environ., 39, 3291-3303, 2005.

Walcek, C. J.: Minor flux adjustment near mixing ratio extremes for simplified yet highly accurate monotonic calculation of tracer advection, J. Geophys. Res., 105, 9335-9348, 2000.

Wesley, M. L.: Parametrization of surface resistances to gaseous deposition in regional-scale numerical models, Atmos. Environ., 23, 1293-1304, 1989. 